\title{
Historical paths of environmental injustice : a century of placing industrial facilities in Helsinki, Finland
}

\section{Schönach, Paula}

2016-04

Schönach , P 2016 , ' Historical paths of environmental injustice : a century of placing industrial facilities in Helsinki, Finland ' , Local Environment, vol. 21 , no. 4 , pp. 397-413 . https://doi.org/10.1080/13?

http://hdl.handle.net/10138/173710

https://doi.org/10.1080/13549839.2014.985641

acceptedVersion

Downloaded from Helda, University of Helsinki institutional repository.

This is an electronic reprint of the original article.

This reprint may differ from the original in pagination and typographic detail.

Please cite the original version. 
This is a pre-copy-editing, author-produced PDF of an article accepted following peer review for publication in Local Environment 21 (4): 397-413.

The definitive publisher-authenticated version is available online, http://dx.doi.org/10.1080/13549839.2014.985641

\section{Historical paths of environmental injustice: a century of placing industrial facilities in Helsinki, Finland}

Paula Schönach

Department of Environmental Sciences,

University of Helsinki, Finland

Email: paula.schonach@helsinki.fi

Acknowledgements

This work was supported by the Academy of Finland under Grant [115527] and Helsinki University Centre for Environment, HENVI [Project: MULTIDOM].

Disclosure statement

There is no conflict of interest related to the possible publication of the research article. 


\title{
Historical paths of environmental injustice: a century of placing industrial facilities in Helsinki, Finland
}

\begin{abstract}
The article explores the historical process of creating unjust environmental conditions in one geographical area in the Finnish capital, Helsinki. The study traces back the decision making processes about placing environmentally burdensome, communal facilities, such as power plants, waste disposal and other infrastructural facilities. Also the lack of environmental amenities is investigated. The study covers a time period from the latter half of the nineteenth century to the 1980s. The historical analysis of the development of land use decisions in the city is based on documentary and archival sources about the decision-making processes and it is conducted in the framework of distributive and procedural environmental justice. Four different periods of siting policies are identified. The motifs for land use decisions at each phase reflect geographical, political and historical reasoning. The concept of path dependency is introduced to explain, how environmental injustices were reproduced because of past paths of siting policies locked in subsequent decisions and created a negative twist of accumulating environmental burden.
\end{abstract}

Key words: environmental justice, distributional injustice, industrial facilities, path dependency, Helsinki

\section{Introduction}

We asked for a health centre, community centre, sports facilities, more parks and a decent waterfront area. We are supposed to get a halfway house for alcoholics, an incinerator, a container dock, a prison and a motorway. Isn't that slightly unfair? (Varvikko 1980) ${ }^{1}$

The close vicinity of polluting municipal service facilities to socio-economically poor residential areas in the Finnish capital, Helsinki, has a long history. The path of locating environmentally unpleasant facilities mainly in the same district (Sörnäinen) was taken for nearly a century. The opening quote reflects the sentiments of a civil group that was formed in 
1980 to oppose the enlargement of a waste incinerator. By then the incinerator had been identified as a major polluter in this area, which had since the latter half of the nineteenth century been location for several plants and factories that caused pollution and degraded the surrounding environmental conditions.

The water front area in this part of the city was mostly inaccessible to citizens in a recreational sense since it was reserved for technical and infrastructural purposes, such as harbors, power plants and depot purposes. The water quality of the bay alongside the area in question was polluted by sewage and industry and swimming baths there were closed already in 1907 due to unhealthy conditions (Kaartinen 1999, p. 71). Also the lack of green space was evident. In 1910 a total of 143 hectares of parks existed in the prosperous neighbourhoods on the other side of the capital, while in the Sörnäinen district the amount was less than half of that (Clark and Hietala 2006, p. 117). In the 1960s the area was declared by the health officials as most affected by air pollution in Helsinki. (Laamanen and Noro 1967, Helsinki City Health Care Board 1977). The same district has also until very recently been predominantly inhabited by socio-economically poor people. Compared to other parts of the city, the population and conditions of this district had been characterised by working-class families with low income, smaller than average housing and higher than average health problems (Waris 1973).

This study takes the unjust outcome described above, namely the obvious geographical environmental differences between urban districts, as a starting point. However, instead of viewing environmental injustices as static outcomes, Pellow (2000, p. 588) and Pulido (2000, p. 14) stress the need to understand the formation of environmental injustices as sociohistorical and socio-spatial processes, respectively. ${ }^{2}$ This article contributes to these objectives and traces back a century of agglomeration of disturbing and polluting activities in one particular area of Helsinki. The emphasis is on understanding the complex process of creating environmental inequality, a continuum of decisions made and actions conducted by various actors that more or less actively infuse injustices into the urban space. (Soja 2010, p. 35, 47, 
Loo 2007, p. 897) As Pulido (2000, p. 13 ) has highlighted, not only the intentional acts of discrimination are of importance, but also the socio-spatial relations that are constitutive powers in the city.

The aim is to describe how this one area became disproportionally burdened with environmentally harmful facilities, to analyse the mechanisms behind this development and to identify key factors contributing to the process. The environmental justice framework attempts to uncover ethical and political considerations about "who gets what, why and how much" (Bullard 2005, p. 433).

The time span covers a period of great societal changes, ranging from the early industrialisation in Helsinki in the late nineteenth century until the 1980s, when the local struggle over the placement of the incinerator became a culmination point of the environmental justice issue. The investigation of one locality over a long period of time helps to identify the context-bound trends of societal decision making processes over siting polluting facilities in a certain geographical area (Szasz and Meuser 1997, Egan 2009, p. 60). The historical analysis of the case is based on documentary evidence about the arguments used in the decision-making process over siting policies.

This article proceeds by elaborating the key concepts of the study and spatial characteristics of the study area. This is followed by a description of four chronologically ordered periods identifying different types of environmental injustices in Helsinki. The conclusions summarize the path of unjust siting policies taken in the city for a century.

\section{Environmental burden and distributional injustice}

The field of environmental justice research is usually divided into several types of (in)justice which, however, are not entirely separable. This article is considering aspects of both distributional and procedural environmental justice, whereof the first refers to the equitable distribution of environmental burdens or benefits among citizens (Kuehn 2000). It has been 
pointed out that the question of distributional justice is inherently a spatial question, why it has been also named also as geographic justice (Hannigan 2002, p. 317, Bullard 2005, p. 436, Soja 2010). Procedural justice can concentrate on processes that lead to unjust outcomes or to the injustices incorporated into the process itself (Boone and Fragkias 2013, p. 51). The key question is the land use patterns that contribute to the occurrence of both environmental benefits and burden, and thus the spatial arrangement of both locally valued and unwanted land use needs to be investigated (Buckley and Boone 2011).

Local environmental burden is produced via concrete constructions placed in urban space, or more precisely through facilities that influence the environment and hence the wellbeing of near-by residents harmfully. As for environmental amenities, they can either be characteristics of the open space, the unbuilt, natural environment and e.g. clean waters, or constructions positively affecting the surrounding environmental quality, such as parks. In a community the important decisions about land use are manifested in the siting policies carried out in the city. The various city-level decisions that determine how environmentally burdensome facilities are placed in urban space together form the siting policies that are in the core of this study.

Urban environmental pollution in Helsinki has been caused throughout the nineteenth and twentieth centuries through common sources. They include untreated or poorly treated sewage in water bodies, smokes and fumes into air from industries, combustion engines and infrastructures related to energy generation and waste management (Laakkonen 2001, Schönach 2008). Sources scattered all over the city have contributed to the overall load, however, large scale facilities have been major concentrated sources of environmental pollution. In terms of environmental injustice the locations of major, municipal service facilities are particularly interesting. These municipally owned and managed facilities produce public goods and services. Constructed with taxpayers' money, they provide benefits for the entire city population and are essential for the functioning of a modern city. However, the 
environmental burden of these activities is carried only by the nearest neighbourhood. The total interest of all citizens contradicts the partial environmental interests of disadvantaged neighbourhoods (Sze 2007, p. 16). This seems to be the case especially with technologies that depend on economies of scale, such as electricity generation plants (Cf. Ottinger 2011). The inhabitants of affected areas seem to accept the presence of private businesses more easily than the location of municipal facilities in their neighbourhood. The placement of burdensome public facilities is more likely to arouse feelings of injustice, since they more clearly benefit the whole community, unlike the economic benefits of private entrepreneurship. Additionally, in Finland the very powerful municipalities are constitutionally obligated to serve the common interest and attend to the inhabitants' welfare. They have a strong authority to decide on the land use planning issues independently (Joas 2001, p. 23).

Additionally, the process of locating the communal service facilities is clearly a question of communal decision making, where the interests of all citizens should be represented. Therefore, this study focuses on the siting process of these, environmentally burdensome municipal service facilities.

As the quote at the beginning of this article reveals, the residents of the area were also dissatisfied with the development of the social environment of their neighbourhood. They for instance objected to the placement of social welfare establishments that were perceived as unpleasant, such as a halfway house for alcoholics. This study, however, concentrates on the natural environmental conditions, i.e. mainly poor air and water quality and the lack of green space. In this paper, I use the super ordinate term 'burdensome conditions', because of the variety of drawbacks the people living in the area experienced. The burdensome conditions created general dissatisfaction with the living environment and small, continuous nuisances present in everyday life.

The historically most important city centre of Helsinki is located on a peninsula jutting out south into the Gulf of Finland (see Figure 1). This study focuses on an area, called 
Sörnäinen, just north-east of the city centre. The Sörnäinen area is separated from downtown by a rather narrow strait, which in turn is crossed by the 'Long Bridge' (Pitkäsilta). The borders of the city of Helsinki have changed during the twentieth century several times through annexations of neighbouring communities. What in the first half of the century was a northeastern district bordering rural regions, became later a district close to the geographical middle of the city. The geographical area in the focus of this paper consists of several adjoining districts, the mainly residential districts of Kallio and Hermanni and the heavily industrial districts of Sörnäinen and Vallila. The district of Kyläsaari comprised for long of mainly waste land and unofficial dumps that formed on new land that had been gained by filling the beachfront area with wastes. For the sake of clarity they all are referred to here as Sörnäinen, where heavy industrial activities first developed and which also in the local language earlier meant everything north of the Long Bridge. 


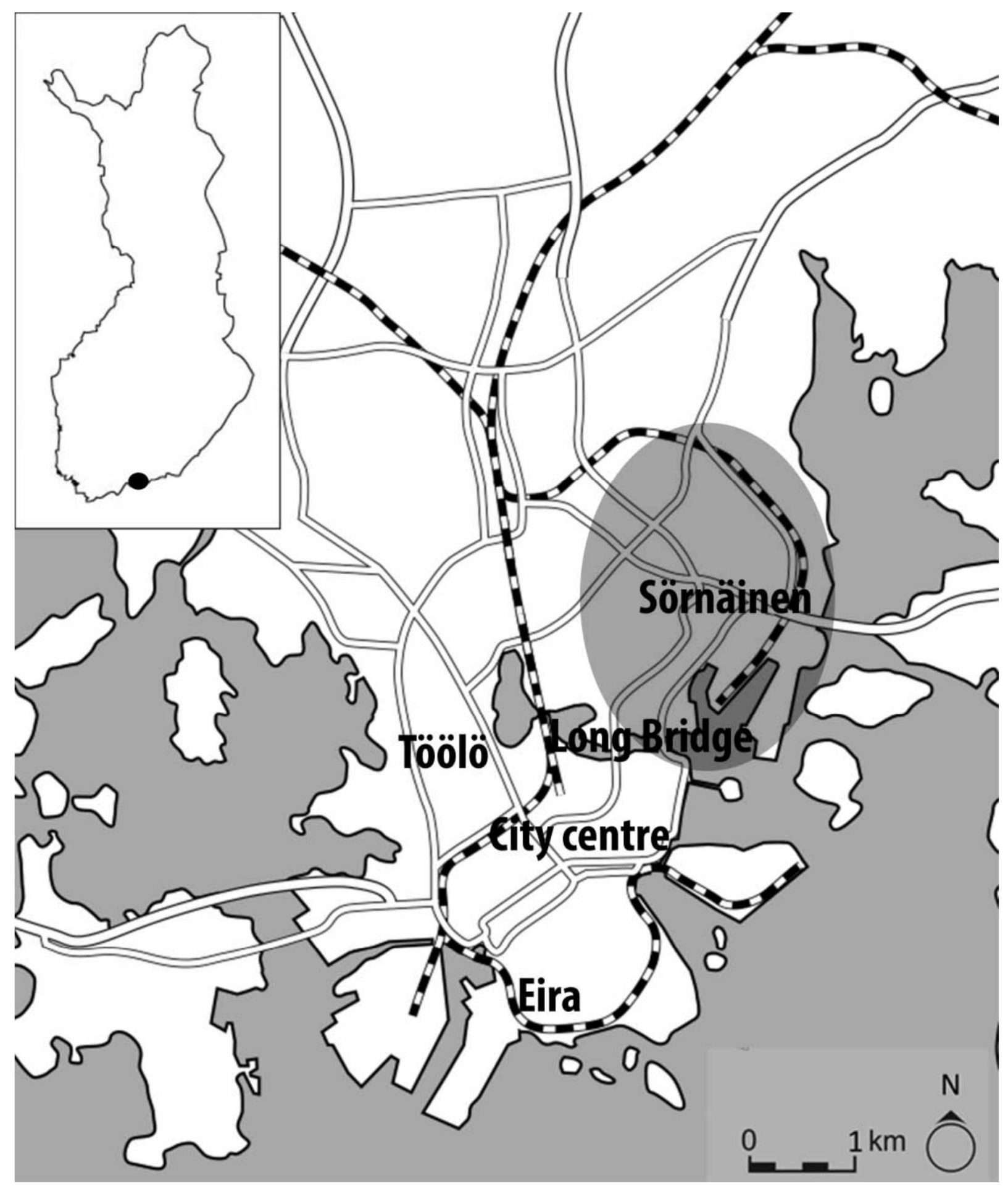

Figure 1. The map of central Helsinki with the railways and major streets. The coastline has changed considerably and here it refers to the present day situation. The heavily industrialised areas in Sörnäinen are marked with grey.

This article doesn't attempt to present a full comparison between different districts of Helsinki, 
but the western district of Töölö forms an important reference point, since the urban residents complaining about environmental injustices referred mainly to the district of Töölö and in several cases, it was discussed as the alternative location for siting communal facilities. In many ways Töölö was originally similar to the north eastern districts: facing the shore, close to a railway connection and close to downtown. As will be shown in following sections, the developmental paths of the two districts resulted in very different outcomes.

\section{The growth of the industrial city and a working class community}

When Helsinki was declared as the Finnish capital in 1812 by the Russian tsar Alexander I it was only a small, backward village with 4.000 inhabitants. However, the rapid growth of the city was under way and a monumental centre in the Empire style was built to highlight the importance and prestige of the city. By the latter half of the nineteenth century it had developed into an administrative, commercial and industrial centre of the country. It was becoming a “metropolis of modest proportions" (Bell and Hietala 2002, p. 134-137). The rapidly growing city attracted workers from the countryside who sought work in the numerous industrial establishments that were founded in Helsinki. Although small workshops were scattered all over the city, industry became concentrated north and north-east of downtown beginning in the 1860s. The first Finnish railway that connected Helsinki with inland cities in 1863 was soon extended by a blind track that led to the newly build port in Sörnäinen. The good transportation infrastructure and plenty of vacant land became an impulse for wider industrial expansion in the area that turned within a few decades into an industrial centre of the city.

Another industrial area was about to form in the south-western part of the downtown peninsula, the district of Eira, which was also designated for industrial purposes. However, as in several European metropolises in the nineteenth century it was recognised that the prevailing western winds would push all the dark smoke over the city centre (Stearns and Chapman 1992, p. 134). Eira-based factories would dirty the new Empire-style centre of the "white daughter of 
the Baltic Sea”, as Helsinki was proud to be called. For hygienic reasons the industries were better based in the north-eastern districts. The location was suitable also from the fire prevention point of view. In 1899 the City Council zoned large areas in the Sörnäinen area for industrial purposes and the zoning for Eira was revised to a villa district (Åström 1956, p. 172, 222).

Together with the expanding industrial activities in the Sörnäinen area, it simultaneously developed into a working class neighbourhood. Uncontrolled migration of poor workers to the capital concentrated to unregulated areas outside the city borders where rental rooms were available to them. The majority of newcomers settled there, close to the places of employment. This was especially important when public transport was poor or unaffordable (Herranen 1988). The main road divided the district with industry on the waterfront side and densely built rental houses, on the other side. The district was the fastest growing in Helsinki during the last decades of the nineteenth century. In 1870 the population counted 1.090 people, and only thirty years later (1900) nearly 22.000 people was living there (Waris 1973, p. 26-27, 61-62)

Social and environmental living conditions in Sörnäinen were poor. Housing conditions were unhealthy, basically slums, with large families sharing one dark room with poor ventilation. In Sörnäinen epidemic diseases were more frequent than in other parts of the city. Ill maintained latrines caused environmental and hygienic problems (Waris 1973). Laundry was rinsed in polluted water and the rising enthusiasm for swimming was hampered by the unhealthy 'nectars' of swimming water. Laakkonen (2001) has shown that swimming opportunities in sea baths were divided in the city by the societal hierarchy, leading finally to the construction of the first indoor swimming hall, practically accessible only to the middleand upper class. Unpaved streets were either sludgy or dusty, smokes and fumes from industries spoiled the air. Also social problems cumulated there. Alcohol was consumed in multiple amounts compared to other districts and the working class area was identified as a 
locus of venereal diseases (Waris 1973). The 'Long Bridge' separating the city centre and this disreputable district became not only a border in terms of land use, but also in the socioeconomic situation of the inhabitants. Besides the physical segregation of the city areas to different functions because of industrialisation, also social differentiation became more evident than before. With the growth of the working class community a new space of societal polarisation became reality (Schulman 2000). The 'length' of the bridge has referred rather to the mental distance between the two worlds on the different sides of the bridge than to the actual width.

While the infrastructural and geographic advantages of the Sörnäinen area attracted entrepreneurs to build their factories there, also the City Council decided to locate two major municipal energy generation facilities there. The location in Sörnäinen was considered ideal for power generation outside suburban dwellings; the railway and port supplied the plant with fuels - wood from inland by train, coal shipped from abroad - and abundant condensation water. The first large scale municipal electricity power plant in Helsinki started operation in Sörnäinen in 1909 (Turpeinen 1984).

The relocation of the gasworks of the city was topical at about the same time. The works that had been founded in 1860 on the outskirts of the contemporary city centre, found itself within the next forty years in the middle of the expanding city. The plant emitted smoke and bad smells that caused a nuisance to the neighbourhood (Herranen 1985, Uusi Suometar 11 Aug 1889, p. 3). In 1900-1909 alternative locations were discussed for the gas plant: the state of the pipe network supported a location in the west, where two different locations were recommended by the gasworks administration and foreign experts. On the other hand, an eastern site was seen beneficial as a place near the new electricity plant would allow them to use a shared coal depot and the electricity plant could use the coke from the gasworks as a fuel (Helsinki City Council Printed Documents 1907a, p. 4). This was, however, the most costly option, because extra pipelines and gas reservoirs would be needed, already existing timber 
yards needed to be moved out of the way and the building site was muddy and required heavy ground work (Helsinki City Council Printed Documents 1907b, Wuolle 1936, p. 88-107). Following the recommendation of the Health Board the City Council settled on Sörnäinen.

First indications of distributional injustice in the rationale of the city officials can be observed when investigating the arguments for the chosen siting policies. The Health Board argued that the western sites were not suitable, because the plant would cause a nuisance to the nearby villa residents (Helsinki City Council Printed Documents 1907b, p. 2, see also e.g. Nya Pressen, 31 Mar 1907, p. 4). Originally the city plan for the western district, called Töölö, designated the area for working class apartments. However, by the turn of the century the plan was changed to meet the housing needs of the growing number of officials. Spacious and elegant, middle-class homes were built instead (Åström 1956, p. 258). The decision of turning Töölö into an exclusively prosperous district for city elites was one important decision that influenced the development of agglomeration of burdensome facilities to the north-east. Applying Laura Pulido's (2000) concept of "white privilege" in the form of "social privilege", as in Finland differences of societal groups have been more based on socio-economic class than race, is a useful tool in trying to understand the roots of environmental injustices. Social privilege can be understood as a social force that works to the benefit of one social group that often is unconscious of its' privileged position. The creation of an urban space and housing area preserved from environmentally burdened land uses can be seen as a foundation and a force to maintain social privilege. Without being necessarily intentionally discriminating, it is, however, impossible to privilege one group without disadvantaging the other. Hence, the preserving of one neighbourhood and its inhabitants from unwanted land-uses inevitable happens at the expense of other less advantageously treated social groups and the areas they inhabit (Pulido 2000).

It was decided to build the gas works in Sörnäinen to spare the western districts from nuisances. The Health Board wanted to prevent complaints that it would have to deal with from 
the influential middle-class residents of Töölö; the dwellings in Sörnäinen near the proposed plant site didn't receive such defendant support. It was rather stated, that the prevailing winds would eliminate the possible nuisances (Helsinki City Council Printed Documents 1907b). The assumption must have been that in Sörnäinen neighbouring citizens would not complain. From the perspective of the environmental burden that these facilities caused to the nearby neighbourhoods an alleged willingness of inhabitants there to accept polluting facilities was built-in (Cf. e.g. Szasz and Meuser 1997, p. 108, Boone and Modarres 1999, p. 175-176).

Gas generation started in Sörnäinen in 1910 next to the site of the power plant. The process of agglomeration of industrial land use in the Sörnäinen area started during the latter half of the nineteenth century and this first phase culminated in the location of two major municipal energy generation plants there. Ringquist's (2000, p. 243-247) has presented a classification of five categories of explanations for the distribution of environmentally harmful facilities. Applied to this first phase of the Sörnäinen case, a scientific rationality, particularly the geography of the area, and market rationality, namely vacant land for industrial expansion, abundant labour force within a reasonable distance and efficient transportation infrastructure, can be identified. Overall, I would like to emphasize the importance of the local, spatial characteristics that were of importance, together with demographic and infrastructural reasons, that favoured the chosen location.

\section{Class conflict and differentiated land use}

The first evidence of residents in Sörnäinen sensing injustice concerning spatial arrangement in their neighbourhood became public during the first decades of the twentieth century. Socialist newspapers complained about the lack of green space in the working class districts and parks were subject to politically charged debate in the municipal government (Lento 2006, p. 194). Inhabitants of the Sörnäinen area gathered in April 1929 for a community meeting and blamed the city for an unbalanced care for different areas. A statement was delivered to the City 
Council and a ten point list of improvements demanded a healthier and more welcoming environment, including the building of parks, playgrounds for children, a swimming facility at the shore and paving of the dusty streets. The shores were polluted by untreated sewage and one demand was to build new pipes to carry the sewage elsewhere (Helsinki City Council, 1929a, see also Kuoppamäki-Kalkkinen, p. 112).

Some members of the City Council were appalled by the demands and openly discriminating statements were uttered: the outskirts of the city were not at the top of the priority list of improvements in the city and the demands were ill-founded. Accusations of favouring middle class areas were considered highly inappropriate. Municipal boards gave their statements on the petition. Mostly the suggested improvements were not to be fulfilled, nor were they included in the development plan of the area. The reasons varied from incomplete zoning processes, lack of finances, to "impracticality" of the proposals. It was also added that it was not justified for citizens to hold "secret meetings" and present such impudent demands to the authorities. In the discussion it was emphasised that the improvements, that eventually would take place, were not due to this letter (Helsinki City Council, 1929a, see also Kuoppamäki-Kalkkinen 1977, p. 112). The response was even bitterer for the workers, because only three weeks later the City Council decided to restore the western waterfront to a beach. Swimming opportunities for the citizens would be enhanced through construction of bathing facilities and the "beautification" of the new green area (Helsinki City Council 1929b). However, the new beach in the west was too far for many worker families to allow regular visits.

The reaction of the City Council to the letter of the workers of Sörnäinen has to be seen in the context of the Finnish class struggle. After independence in 1917, a civil war between the non-socialists and the socialist, working class broke out. The war was very violent and after the conquest of the working class revolts an atmosphere of accusations and suspicion prevailed in the divided society for decades (See e.g. Upton 1980). The right-wing majority in the City 
Council had little sympathy for the issues of working class people (Kuoppamäki-Kalkkinen 1977, p. 113). The mention of condemnable "secret meetings" of workers refers to the revolutionary past and reveals the suspicious attitude of some right representatives in the Council towards initiatives from the working class. This originates in the traumatic experience of the civil war, only one decade earlier.

The only demand that was approved as justified in the Council was that of the sewage water contaminating the waterfronts of the bay (Helsinki City Council 1929a). However, the measure undertaken was not what had been hoped for. Instead of directing the sewage to some other place it was decided to build a sewage treatment plant, which started in 1932. The idea was to improve the environmental conditions, but the plant itself turned out to be a major nuisance, apart from the fact, that it was soon over capacity because of the housing expansion and new districts that were connected to the plant. Sewage was still often let untreated to the water (Laakkonen and Lehtonen 2001, Juuti, Rajala and Katko 2010, p. 65). ${ }^{3}$ The citizen's original wish to improve their local environment and the recreational value of the shore turned out into deploying the water front area to industrial land use in the form of the treatment plant, and considerably increasing amounts of variably purified wastewater polluting the water. The waste water treatment plant destined the area for these burdens for a long time. Additionally, it also strengthened a path to similar land use patterns in the future.

At the same time the tendency to spare the western shore and its neighbouring district Töölö from environmental burden strengthened. A free port that was suggested to the western shore by a foreign expert was heavily opposed by the city plan architect and the city engineer because they didn't want to sacrifice the large parks and villa areas to port uses and Töölö would lose its "peaceful and noble" character (Helsinki City Council Printed Documents 1920, 13-14, Erävuori 1981, p 91-94). During the 1930s also the city's slaughterhouse was relocated from the western shore to Sörnäinen. The slaughterhouses' previous location in the western part was considered unsuitable, because with its smelly wastes it detracted from the new beach 
(Åström 1956, p. 258). These decisions of securing and enhancing the environmental amenities in this middle- and upper class district reflect the social privilege that was incorporated in the structures of urban development in Helsinki. Concentrations of degraded environments are products of relationships between distinct places (Pulido 2000, p. 13) and in the case of Helsinki, the mainly working class districts were on the disadvantaged side of this relationship.

The turbulent 1920s and 1930s mark a second phase of siting policies of both burdensome facilities and environmental amenities in Helsinki. Downright discrimination and a lack of political power and resources on the other hand can be identified (Cp. Ringquist 2000, p. 246). As a legacy of the rebellion from the workers' side, the inferior conditions of working class districts may even have been seen as justified since they were supposedly the source of revolutionary evil. The left-wing minority in the City Council and conservative sympathies in the administrative organs left few possibilities for the working-class neighbourhoods to fight for improvements in their surroundings. Additionally, the culture of city planning in Helsinki traditionally emphasised the power of city officials and experts on the boards (Kolbe 2002, p. 24, 61). The general and equal enfranchise, introduced in Finland in 1907, did not decidedly improve the possibilities for non-elite groups to influence the development of urban planning (Kuoppamäki-Kalkkinen 1977, p. 11). It was not until the uniting war experience of WWII and the post-war years, that obvious class struggle was surmounted.

\section{Locked-in path of post-World War II industrial siting}

The decades following the World War Two were marked with a recovering economy, rising living standards and modern amenities becoming the norm, especially in cities. This rapid modernisation of the society was accompanied with a growing energy demand and increasing amounts of waste produced. Large investments in power plant construction and waste incineration were made during the 1950s and 1960s. Although construction works in an industrial area in the south-western shore of the urban peninsula intensified as well, however, 
the majority of facilities causing environmental ills were mostly located in the Sörnäinen area. This time the arguments for the biased siting policies of the city were motivated by the preexisting facilities.

A new power plant could use gas from the gas works and replace in the future the old power plant. An incinerator was marketed as a power plant, which could supply the district heating system. To save pipe construction costs it should be sited close to the power plant. Also the sludge from the sewage treatment plant could be easily and cheaply transported to the incinerator for burning. The slag from the incinerator could be used to fill the wasteland close to the shore and gain new land for the expansion of port activities. Coke that would be burned as an additional fuel was produced at the gas works, which again was conveniently located in the vicinity (Helsinki City Council 1949, Helsinki City Board of Public Works, 1956). As an additional consequence, in 1955 it was decided to gradually relocate the coal harbour, which spread coal dust around its neighbourhoods, from the western harbour to the east, since the majority of coal was used there. This was done despite e.g. the fact that coal dust was seen especially harmful to food industries that were located there as well (Helsinki City Council Printed Documents, 1955, Helsinki City Council 1955).

The large public plants formed a network of sanitary necessities and important infrastructures to keep the modern city running. The district had developed into an infrastructural hub. The near-by locations provided mutual benefits and the agglomeration of the plants in one district was rational in terms of synergy benefits. The placement policies of public facilities in the past decades had laid foundations on the urban infrastructure systems that were heavily expanded in the post-war years. The concept of path dependency is here useful in supplementing the analysis of traditional historical causation. It has been used e.g. by the urban environmental historian Martin Melosi $(2000,2005)$ to give new insight to the development of urban environments. In the context of placing industrial facilities and environmental injustices it captures the rationality of the siting policies. Previous decisions and 
choices might restrict the available options in the future and lock-in the decision making process to certain, possibly inferior or unjust, choices, while locking-out some others. Broadly seen it suggests the rather self-evident notion, that a situation is conditioned and influenced by the past - there exists a "sensitive dependence on initial conditions" (Liebowitz and Margolis 1995, p. 206). ${ }^{4}$ However, in this case the question is not about the efficiency of the results, rather than the environmental justifiability of the process and the outcome.

The notion of geographically uneven developments having cumulative causal backgrounds was presented already in the 1950s by Gunnar Myrdal. He points out how initial conditions, both negative and positive, tend to accumulate and thus contribute to increasing inequalities among places (Myrdal 1957). As Arthur (1988) has shown for industries, under certain circumstances they tend to agglomerate to nearby locations for mutual benefits. This seems to be the case in Helsinki; in terms of coherent land use and economically favourable planning, it became reasonable to accumulate burdensome activities in the Sörnäinen area. The environmental burdens of these establishments concentrated in the neighbourhoods that had grown over the decades even closer to the polluting plants. The earlier set of events start an institutionalised pattern of decision making, which delivers increasing benefits with continued adoption. The pattern reproduces itself and path dependency can be seen as a self-reinforcing sequence of events (Mahoney 2000). The accumulation of burdensome facilities in one disadvantaged neighbourhood was at this point an unintended consequence of past, at least partially intentionally unjust, siting decisions. The earlier decisions led to a path-dependent rationale, where the link-up of different facilities justified the placement of new facilities in the same geographical area.

\section{A re-direction of an unjust path}

The obvious differences in the environmental conditions of the eastern and western shores of the city rose senses of injustice in the residents of Sörnäinen during the post-war decades. A 
man living in the burdened district captured the sentiments in his complaint to the authorities in 1956: “our tax money does nicely for building playgrounds and parks in Töölö; these shores won't see a penny of that money" (Helsinki City Health Care Board 1956). Awareness and recognition of the situation was gradually increasing and the subject was brought up in the media, locals and, increasingly acknowledged also at the city administration (e.g. Launis 1972, p. 80; Kansan Uutiset 10 Aug 1966; Uusi Suomi 11 Sep 1968, p. 12; Paavola 1968; Varvikko 1972, Snellman 1973). The Health Board dealt with regular complaints about air pollution smoke, odour and coal dust. Visible decay was complemented with research based knowledge on the poor environmental condition in the area. The Institute of Occupational Health ascertained that the area was the dirtiest and most polluted in town (Laamanen and Noro 1967, Schönach 2008, p. 182). Some gradual technical improvements were possible in terms of filtration and other air protection measures, but the area remained heavily disadvantaged in comparison to other areas.

During the 1970s plans on the future land use of the area was dominated by two contradicting trends. Near-by residents had high expectations as the proposal for the new master plan in 1970 suggested considerable improvements to the environmental conditions of the Sörnäinen area through the creation of new recreational areas (Helsingin kaupunki 1970). However, the northern end of the affected area had large un-zoned areas, waste land, which left them open also for new, burdensome land uses. A new wave of plans for re-location of services with deteriorating environmental effects became public. These included a new temporary coal reservoir, the division of a park area with a new main transit road for motor vehicles, building of a plant for treatment of toxic waste collected from all of southern Finland, concentration of the sludge treatment of the whole city to the existing waste water treatment plant and finally, the enlargement of the highly polluting incinerator to treat threefold amounts of waste (Ongelmajätetoimikunnan mietintö 1975, Helsinki City Government 1972 a, 1972b, Helsinki 
City Board of Public Works 1980, Helsinki City Council Printed Documents 1981; Hufvudstadsbladet, 5 Jan 1975, 1, 24).

These placements were once again argued to be the most rational and cost efficient, since the existing infrastructures supported the establishment of these new facilities. The location was ideal for a centralised toxic waste treatment plant, because of convenient distances from everywhere and good transportation facilities. Vacant land was available for the plant as well as the slag. Heat generated by waste incineration could be piped to the power plants. The earlier paths taken locked-out other locations in the city as economically suitable places and strongly supported the further accumulation of all major municipal service operations in that area. The Board for Public Property claimed that the area had a "traditional character as a site for waste treatment" and that the residents were used to these activities (Helsinki City Government, 1972a, 1972b). As Edward Soja (2010, p. 41) has stated, once spatial injustice is inscribed in the built environment, it is difficult to erase. In this case it seemed even to be normalized.

In the case of Sörnäinen, the hopes that had been raised by the optimistic prospects of new plans and the collapse of these expectations to the worst case scenarios sparked off a large scale mobilisation of resistance (Hänninen 1991, p. 228). In 1980 a communal group was formed around active local inhabitants and strong pressure against these environmentally deteriorating plans was advanced. With skilful and clever political resistance the movement gained popularity and, eventually managed to prevent the plans for further waste treatment facilities in the district from being realised. The success of the movement culminated in the closure of the incinerator in 1983. The details of the anti-incineration-struggle are beyond the scope of this article, and are analysed elsewhere (Hänninen 1991, 1992), however, it seems to be a key moment in changing the path of distributional, environmental injustice.

The closure of the incinerator was a turning point in the accumulation of burdens in Sörnäinen. The sewage treatment plant was closed in 1994; two of the power plants were 
closed in 1974 and 2000 respectively and substituted by a plant whose environmental standards were substantially higher than its predecessors'. The gas works had already earlier changed to a fluid gas, which lessened the nuisances caused by the gas generation process and coal dust. Also several parks had been upgraded in Sörnäinen. Even if some burdensome municipal facilities still are left, the path of concentrating them in this one district had changed.

The historical context, where active and passive deteriorating of environmental conditions was carried out earlier, had, if not reversed, at least redirected the path dependent development paradigm. By the 1980s, the attitudes towards pollution and a degraded living environment had changed compared to pre-war decades. The newest plans of accumulating more environmental disamenities into one area exceeded a critical boundary of local acceptance. As Massard-Guilbaud and Rodger (2011a, p. 34) have pointed out, what is considered reasonable and acceptable changes over time and is affected by the knowledge at hand and by comparisons to other places. In the case of Sörnäinen, the acceptability of pollution and an unpleasant environment was no longer compatible with the earlier impression of the Board for Public Property.

\section{Conclusions}

This article presents a historical chronology of the accumulation of environmentally burdensome municipal service facilities in one geographical area in north-eastern Helsinki. At the same time the western part of the city was deliberately spared from nuisances caused by these industrial facilities. The development created a city-wide unjust spatial distribution of the harms related to these municipal functions. Three different types of spatial and distributional environmental injustice were discussed. Firstly, the locating of burdensome facilities to one disadvantaged area, which means active measures that change the environmental conditions in a certain area. Secondly, the rejection or postponement of environmental improvements in the disadvantaged area was observed. This could be described as a passive way of degenerating the 
environmental conditions. And finally, the reversed perspective of injustice: the tendency to preserve certain areas free from burdensome facilities and offer there an abundance of environmental amenities, such as recreational areas, parks and other services that in general are perceived as adding value to the living environment.

The study of long-term siting policies revealed four distinct periods with context bound characteristics that affected the political processes that led to unjust siting decisions. The argumentation and reasoning behind the unjust development varied over the years. During the first, intense industrialisation phase in the latter half of the nineteenth century, locating burdensome facilities in the poor working-class area was rationalised with geographic, demographic and infrastructural considerations, though different alternatives were also considered and held in many respects for better solutions. This was the case e.g., with the gas works and industrial sites in the southern end of the Helsinki peninsula. Favourable conditions in Sörnäinen meant the availability of vacant, remote land as well as accessibility of transport services and labour force. The train track and port built before made the locations attractive to activities relying on the import of fuels. Nuisances from air pollution could be minimised by being far enough down-wind of the city centre.

During the second phase after independence in the first half of the twentieth century, all three different types of distributional injustices and procedural injustice were characteristic. Services in the western districts of the city were actively promoted and burdensome facilities were re-located from prosperous districts to Sörnäinen to spare the wealthy, middle-class residents from nuisances. Public acceptance of burdensome plants was considered better in low-income districts, where citizens were used to industrial fumes and had no powerful representatives in the decision-making process. At the same time the demands for improvements in the living environment there were rejected. Driven by social privilege, a benefit for one district meant a heavier burden somewhere else, because the public facilities were essential for the entire urban system. The spatial character of environmental injustice 
becomes evident in the unbalanced relationship between the environmental burdens laid on distinct urban spaces.

Environmental improvements in the disadvantaged district were denied in the politically tense period of class struggle. The shadows of the national trauma, the civil war, were visible in the passive discrimination of the working-class urban environment in the 1920s and 1930s. Environmentally unjust decisions added to the circumstances that later led to selfreinforcing siting policies.

The third, post-war phase was characterised by generally higher living standards and a rapid modernisation of city life. The burdensome facilities were sited in the Sörnäinen area, but now the background of the decisions could be described as path-dependent. The existing facilities meant synergy benefits for the planning of new plants, which led to the accumulation of the burdens in the already disadvantaged district. The decisions made more than a half century earlier resulted in a negative twist of increasing environmental burden - the pattern of siting burdensome facilities in Sörnäinen reproduced itself, since it had become rational and efficient to concentrate the plants in one area. The decisions made fifty years earlier had locked in the future options and the most rational thing to do was to continue along the chosen path. The economic rationale basically eliminated the other options as the usage of already existing infrastructures was always the most inexpensive one. The path-dependent decision making process hid the partly discriminating initial backgrounds and paved the way for rational and cost efficient locating strategies that at the same time changed the environmental conditions of the citizens in a very unequal way.

However, the case of Sörnäinen in Helsinki shows also that the development path can be redirected in a positive way. In the fourth phase during the 1970s and early 1980s further accumulation of burdensome facilities in the area was foreseeable, but local resistance redirected the path and stopped the development of further increase of unjust conditions. 
The study at hand contributes in several ways to existing environmental justice literature and theory. It adds to the relatively small number of case studies in the European context and broadens the geographic scope of environmental justice research to the Nordic countries, where environmental justice issues have gained only little attention so far. (see e.g. Bradley et al. 2008, p. 70) Despite of their very different histories the Nordic countries are often together labelled as the models of egalitarian societies, however, this case shows that this widely spread myth requires critical inspection. The current case study offers new insight to the issue from the Finnish perspective and an investigation of the urban development over time reveals the deep historical roots of environmental (in)justice that can be found in a Nordic country, as well.

While the existing literature on distributive environmental justice tends to neglect the historical background in explaining the creation of environmental injustices, this study has highlighted the importance of historical analysis in order to increasing our understanding on the reasons for environmental injustices. Furthermore, the study extends the scope of the historical analysis to process equity, which is so far underrepresented in the literature. The historical view point of the case reveals that the process of creating environmental injustices can involve several distinct phases, which are characterised by different types of injustices and that existing injustices are sustained through path dependent development patterns. The case reaffirms the simple notion that the past matters and this should be taken seriously when attempting to understand environmental injustices.

\section{Notes}

1. Hermanni-Vallila is a local district newspaper. Translation of the quote by the author.

2. The importance of the historical perspective within environmental justice research has been highlighted and it has increased greatly within the last decade. (E.g. Szasz and Meuser 1997, Callewaert 2002, Egan 2002, Krieg 2005, Luckin 2005) Also a number of contributions 
overlapping urban environmental history and themes in environmental justice have been published recently, notably the articles in the edited volume by Massard-Guilbaud and Rodger (2011b) and e.g. Klingle (2006). In the Finnish context the view point of environmental justice in urban (environmental) history research has lacked so far nearly entirely, only one study by Kuoppamäki-Kalkkinen (1977) has touched upon justice issues in the context of urban planning.

3. In the late 1960s the plant was out of use for more than a year due to enlargement works constructed at the plant.

4. The discussion around the path dependency theory is a broad field since 1985 when it was discussed by Paul David (1985). The QWERTY typewriting keyboard is an example of path dependency. It effectively prevented the jamming of the keys, was adopted largely and became the dominant keyboard type, even if others proved to be more efficient. The path seems to result in inflexibility and inhibit change into another technology since the dominant one is locked-in.

\section{References}

Arthur, B., 1988. Urban Systems and Historical Path Dependence. In: J. Ausubel and R. Herman, eds., Cities and their Vital Systems: Infrastructure Past, Present and Future. Washington: National Academy Press, 85-97.

Åström, S., 1956. Helsingfors stads historia. Stadssamhällets omdaning / 4. delen, 2. bandet, Perioden 1875-1918. Helsingfors: Helsingfors stad.

Bell, M., and Hietala, M., 2002. Helsinki: the innovative city: historical perspectives. Helsinki: Finnish Literature Society, City of Helsinki Urban Facts.

Boone, C.G. and Modarres, A., 1999. Creating a Toxic Neighborhood in Los Angeles County: A Historical Examination of Environmental Inequity. Urban Affairs Review, 35 (2), 163-187.

Boone, C.G. and Fragkias, M., 2013. Connecting Environmental Justice, Sustainability, and Vulnerability. In: C.G. Boone and M. Fragkias, eds. Urbanization and Sustainability: Linking Urban Ecology, Environmental Justice and Global Environmental Change. New York: Springer, 49-60.

Bradley, K., Gunnarsson-Östling, U. and Isaksson, K., 2008. Exploring Environmental Justice in Sweden - How to improve planning for environmental sustainability and social equity in an "eco-friendly" context. Projections: MIT Journal of Planning, 8, 65-81. 
Buckley, G.L., and Boone, C.G., 2011. To Promote the Material and Moral Welfare of the Community. In: G. Massard-Guilbaud and R. Rodger, eds. Environmental and Social Justice in the City: Historical Perspectives. Cambridge: White Horse Press, 43-66.

Bullard, R.D., 2005. Environmental Justice in the 21st century. In: J. Dryzek and D.

Schlosberg, eds. Debating the Earth: The Environmental Politics Reader. 2nd edition. Oxford: Oxford University Press, 431-449.

Callewaert, J., 2002. The Importance of Local History for Understanding and Addressing Environmental Injustice. Local Environment, 7 (3), 257-267.

Clark, P., and Hietala, M., 2006. Helsinki and Green Space 1850-2000: an Introduction. In: P. Clark, ed., The European City and Green Space: London, Stockholm, Helsinki and St. Petersburg, 1850-2000. Aldershot: Ashgate, 175-187.

David, P., 1985. Clio and the Economics of QWERTY. The American Economic Review 75 (2), 332-337.

Egan, M., 2002. Subaltern Environmentalism in the United States: A Historiographic Review. Environment and History, 8 (1), 21-41.

Egan, M., 2009. The Relevance of History to Environmental Justice. Environmental Justice, 2 (2), 59-61.

Erävuori, J., 1981. Helsingin sataman ja satamahallinnon historia. Helsinki: Helsingin kaupunki.

Hannigan, J.A., 2002. Cultural Analysis and Environmental Theory: An Agenda. In: R.E. Dunlap, F.H. Buttel, P. Dickens and A. Gujswijt, eds., Sociological Theory and the Environment. Lanham MD: Rowman and Littlefield Publishers, 311-326.

Hänninen, S., 1991. Pollution, Power and Participation in Finland. In: T. Deelstra and O. Yanitsky, eds., Cities of Europe: The Public's Role in Shaping the Urban Environment. Moscow: Mezhdunarodnye othoshenia, 225-235.

Hänninen, S., 1992. How to Combat Pollution by Words. Alternatives, 17 (2), 209-229. Helsingin kaupunki, 1970. Helsinki:Yleiskaavaehdotus 1970. Parts 1 and 2. Helsinki: Helsingin kaupungin kaupunkisuunnitteluvirasto, yleiskaavaosasto.

Helsinki City Board of Public Works, 1956. Protocol 6 Feb 1956, 194§. Cb:24, Helsinki City Archive.

Helsinki City Board of Public Works, 1980. Protocol 24 Apr 1980, 590§. Helsinki City Archive.

Helsinki City Council, 1929a. Protocol and Appendices 23 Oct 1929, 35§, Appendix A and Minutes of the Discussion. Ca:83, Helsinki City Archive. 
Helsinki City Council, 1929b. Protocol 13 Nov 1929, Ca:83, Helsinki City Archive.

Helsinki City Council, 1949. Protocol and Minutes of the Discussion 14 Dec 1949, 646§.

Ca:130-131, Helsinki City Archive.

Helsinki City Council, 1955. Protocol 30 Nov 1955, 1049§. Ca: 181, Helsinki City Archive.

Helsinki City Council Printed Documents, 1907a. Report Nr 2. of the Committee on the construction of a communal electricity plant, 24 / 1907, Helsinki City Archive.

Helsinki City Council Printed Documents, 1907b. Documents that relate to the construction of the new gas works to Helsinki, 28 / 1907, Helsinki City Archive.

Helsinki City Council Printed Documents, 1920. Report Nr 1 of the Harbour Committee 15 / 1920, Helsinki City Archive.

Helsinki City Council Printed Documents, 1955. Report of the Committee on the development of the harbours in Helsinki, 18 / 1955, Appendices. Helsinki City Archive.

Helsinki City Council Printed Documents, 1981. Memorandum on the organisation of waste management $10 / 1981$. Helsinki City Archive.

Helsinki City Government, 1972a. Protocol 10 Apr 1972, 1101§. Ca: 42, Helsinki City Archive.

Helsinki City Government, 1972b. Appendices 10 Apr 1972, 1101§, Appendix 3 and 6. Cb: 598 Helsinki City Archive.

Helsinki City Health Care Board, 1956. 30 May 1956, 403§. Ca:122-123. Helsinki City Archive.

Helsinki City Health Care Board, 1977. Monitoring Division 26 Jan 1977, 2037§, App 1. Ca:336, Helsinki City Archive.

Herranen, T., 1985. Kaasulaitostoimintaa Helsingissä 1860-1985. Helsinki: Helsingin kaupungin energialaitos.

Herranen, T., 1988. Hevosomnibusseista metroon: vuosisata Helsingin joukkoliikennettä. Helsinki: Helsingin kaupunki.

Hufvudstadsbladet 1975. Blyet i Hfrs-luften inte bara bilarnas fel. Hufvudstadsbladet, 5 Jan, pp. $1,24$.

Joas, M., 2001. Reflexive modernisation of the environmental administration in Finland: essays of institutional and policy change within the Finnish national and local environmental administration. Åbo: Åbo Akademi University Press.

Juuti, P., Rajala, R. and Katko, T., 2010. Metropoli ja meri: 100 vuotta jätevedenpuhdistusta Helsingissä. Helsinki: Helsingin seudun ympäristöpalvelut. 
Kaartinen, A., 1999. Uiminen on liikkumalla kylpemistä. In: S. Laakkonen, S. Laurila and M. Rahikainen, eds., Nokea ja pilvenhattaroita: Helsinkiläisten ympäristö 1900-luvun vaihteessa. Helsinki: Helsinki City Museum, 62-74.

Kansan Uutiset 1966. Jätkän hiilisatama Sörnäisiin, kaupungin vapaavarasto tuhotaan, tehdäänkö tällainen hulluus? Kansan Uutiset, 10 August, p. 10.

Klingle, M., 2006. Changing Spaces: Nature, Property and Power in Seattle, 1880-1945. Journal of Urban History, 32 (2), 197-230.

Kolbe, L., 2002. Helsinki kasvaa suurkaupungiksi. Julkisuus, politiikka, hallinto ja kansalaiset 1945-2000. In: L. Kolbe and H. Helin, eds., Helsingin historia vuodesta 1945. Part 3, Helsinki: Helsingin kaupunki, 13-511.

Kuehn, R., 2000. A Taxonomy of Environmental Justice. Environmental Law Reporter, 30 (9), 10681-10703.

Kuoppamäki-Kalkkinen, R., 1977. Katsaus kaupunkikehitykseen ja kaupunkisuunnitteluun Helsingissä 1870-1970. Espoo: Teknillinen korkeakoulu.

Laakkonen, S., 2001. Vesiensuojelun synty: Helsingin ja sen merialueen ympäristöhistoriaa 1878-1928. Helsinki: Gaudeamus.

Laakkonen, S., and Lehtonen, P., 2001. Mikrobit palveluksessa: Jätevedenpuhdistuksen kehitys Helsingissä. In: S. Laakkonen, S. Laurila, P. Kansanen and H. Schulman, eds., Näkökulmia Helsingin ympäristöhistoriaan: Kaupungin ja ympäristön muutos 1800- ja 1900-luvuilla. Helsinki: Helsingin kaupungin tietokeskus, 226-239.

Laamanen, A., and Noro, L., 1967. Helsingin ilman saasteen lähdeyhtymäkatsaus ja siihen liittyvät kaupunkikohtaiset ilmansuojelunäkymät. 34. Helsinki: Työterveyslaitos.

Launis, T., 1971. Helsinki : Yleiskaavaehdotus 1972. Ympäristönsuojelun esiselvitykset Helsingin 1972-1973 yleiskaavoituksessa. Helsinki: Kaupunkisuunnitteluvirasto. Yleiskaavaosasto.

Lento, K., 2006. The role of nature in the city: green space in Helsinki 1917-1960. In: P. Clark and M. Hietala, eds., The European City and Green Space: London, Stockholm, Helsinki and St. Petersburgh, 1850-2000. Aldershot: Ashgate, 188-206.

Liebowitz, S.J., and Margolis, S., E., 1995. Path-Dependence, Lock-In, and History. Journal of Law, Economics and Organization, 11 (1), 205-226.

Loo, T., 2007. Disturbing the Peace: Environmental Change and the Scales of Environmental Justice on a Northern River. Environmental History, 12 (4), 895-919.

Luckin, B., 2005. Environmental Justice, History and the City: The United States and Britain 1970-2000. In: D. Schott, B. Luckin and G. Massard-Guilbaud, eds., Resources of the 
City: Contributions to an Environmental History of Modern Europe. Aldershot: Ashgate, 230-245.

Mahoney, J., 2000. Path dependence in historical sociology. Theory \& Society, 29 (4), 507548.

Massard-Guilbaud, G., and Rodger, R., 2011a. Reconsidering Justice in Past Cities: When Environmental and Social Dimensions Meet. In: G. Massard-Guilbaud and R. Rodger, eds., Environmental and Social Justice in the City: Historical Perspectives. Cambridge: White Horse Press, 1-40.

Massard-Guilbaud, G., and Rodger, R., eds., 2011b. Environmental and Social Justice in the City: Historical Perspectives. Cambridge: White Horse Press.

Melosi, M.V., 2000. The sanitary city: urban infrastructure in America from colonial times to the present. Baltimore (Md.): Johns Hopkins University Press.

Melosi, M.V., 2005. Path Dependence and Urban History: Is a Marriage Possible? In: D. Schott, B. Luckin and G. Massard-Guilbaud, eds., Resources of the City: Contributions to an Environmental History of Modern Europe. Hampshire: Ashgate, 262-275.

Myrdal, G., 1957. Rich lands and poor: the road to world prosperity. New York: Harper \& Row.

Nya Pressen 1907. Det nya gasverket. Nya Pressen, 31 Mar, p. 4.

Ongelmanjätetoimikunnan mietintö, 1975. 102. Helsinki: Sisäasiainministeriö (Ministry of the Interior). [Report of the hazardous waste committee].

Ottinger, G., 2011. Environmentally Just Technology. Environmental Justice, 4 (1), 81-85.

Paavola, E.J., 1968. Piipun takaa. Helsinki-Lehti, 29 Nov, p. 2.

Pellow, D., 2000. Environmental inequality formation: toward a theory of environmental justice. American Behavioral Scientist, 43 (4), 581-601.

Pulido, L., 2000. Rethinking environmental racism: White privilege and urban development in Southern California. Annals of the Association of American Geographers, 90 (1), 1240.

Ringquist, E., 2000. Environmental Justice: Normative Concerns and Empirical Evidence. In: N. J. Vig J. and M. Kraft E., eds., Environmental Policy. Fourth edn. Washington, D.C.: CQ Press, 232-256.

Schönach, P., 2008. Kaupungin savut ja käryt: Helsingin ilmansuojelu 1945-1982. Thesis (PhD). University of Helsinki.

Schulman, H., 2000. Helsingin suunnittelu ja rakentuminen. In: H. Schulman, P. Pulma and S. Aalto, eds., Helsingin historia vuodesta 1945: osa 2. Helsinki: Edita, 12-111. 
Snellmann, T., 1973. Sörnäs strand - den stinkande stadsdelen. Hufvudstadsbladet, 11 May, 2. Soja, E.W., 2010. Seeking spatial justice. Minneapolis: University of Minnesota Press.

Stearns, P.N., and Chapman, H., 1992. European society in upheaval: social history since 1750. 3rd ed. New York: Macmillan.

Szasz, A., and Meuser, M., 1997. Environmental inequalities: literature review and proposals for new directions in research and theory. Current sociology, 45 (3), 99-120.

Sze, J., 2007. Noxious New York: the racial politics of urban health and environmental justice. Cambridge, Mass: MIT Press.

Turpeinen, O., 1984. Energiaa pääkaupungille : sähkölaitostoimintaa Helsingissä 1884-1984. Helsinki: Helsingin kaupungin energialaitos.

Upton, A.F., 1980. The Finnish revolution 1917-1918. Minneapolis: University of Minnesota Press.

Uusi Suometar 1889. Käynti Helsingin tehtaissa. Uusi Suometar, 11 Aug, p. 3.

Uusi Suomi 1968. Vanhankaupungin selän länsiranta kunnostettava. Uusi Suomi, 11 Sep, p. 12.

Varvikko, K., 1972, Hermannin kevään tuoksut. Suomen Sosialidemokraatti, 25 March, p. 4.

Varvikko, K., 1980. "Kaupunginjohtaja Raimo Ilaskivi: Jätteet sopivat parhaiten korpeen". Hermanni-Vallila 2/1980, p. 4.

Waris, H., 1973. Työläisyhteiskunnan syntyminen Helsingin Pitkänsillan pohjoispuolelle. 2. ed. Helsinki: Weilin+Göös.

Wuolle, B., 1936. Helsingin kaupungin kaasulaitos 1860-1935. Helsinki: S.n. 